\title{
Osteology of a perinatal aristonectine (Plesiosauria; Elasmosauridae)
}

\author{
JOSÉ P. O'GORMAN ${ }^{1,2}$, MARIANELLA TALEVI ${ }^{2,3}$ and MARTA S. FERNÁNDEZ ${ }^{1,2}$ \\ ${ }^{1}$ División Paleontología Vertebrados, Museo de La Plata, Universidad Nacional de La Plata, Paseo del Bosque s/n, B1900FWA, \\ La Plata, Argentina \\ ${ }^{2}$ CONICET, Consejo Nacional de Investigaciones Científicas y Técnicas, Argentina \\ ${ }^{3}$ Instituto de Investigación en Paleobiología y Geología Universidad Nacional de Río Negro-CONICET, Av Roca 1242, R8332EXZ \\ General Roca, Río Negro, Argentina \\ joseogorman@fcnym.unlp.edu.ar
}

\begin{abstract}
Perinatal specimens give valuable information about the first stages of vertebrate ontogeny. Here, the morphology and palaeohistology of an aristonectine perinatal specimen from Seymour Island (Isla Marambio), López de Bertodano Formation are analysed. The palaeohistological analysis shows incomplete endochondral ossification (retention of a calcified cartilaginous core in the medullary region), predominance of primary bone tissue without secondary remodelling, lack of primary or secondary osteons and of growth marks in the cortical bone, and open vascular spaces not surrounded by a thin coat of lamellar bone tissue. General lines of morphological changes were inferred from comparing the fossil with an adult aristonectine specimen indicating i) a tendency of relatively high and broad posterior cervicals to decrease during ontogeny, ii) a decrease of relative size of the dorsolateral process and an increase of the glenoid ramus and iii) the existence of two separate stages in propodial growth divided into an initial elongation followed by a distal expansion. The presence of a perinatal specimen in the James Ross Archipelago indicates that the region was used as a breeding area by the aristonectines during the last part of the Cretaceous.
\end{abstract}

Received 3 March 2016, accepted 1 June 2016

Key words: Aristonectinae, marine reptile, perinatal, Upper Cretaceous, Weddellian Province

\section{Introduction}

Elasmosaurids are the most diverse Late Cretaceous plesiosaur group achieving a worldwide distribution (Welles 1962, Vincent et al. 2011, Kubo et al. 2012). The record of elasmosaurids from Antarctica is restricted to the James Ross Archipelago (Fig. 1), where they have been collected from the Santa Marta Snow Hill Island and López de Bertodano formations (O'Gorman 2012, table II). The elasmosaurid fauna from the Weddellian Province sensu Zinsmeister (1979), i.e. Patagonia, western Antarctica and New Zealand, comprises aristonectine and non-aristonectine elasmosaurids (Gasparini et al. 2003, O'Gorman et al. 2015). Despite the initial controversy about the elasmosaurid affinities of aristonectines (Welles 1962, O'Keefe \& Hiller 2009), the interpretation is now widely accepted (Gasparini et al. 2003, Otero et al. 2014, O'Gorman et al. 2015). Another contentious issue surrounding the aristonectines is the explanation for the large quantity of specimens that show juvenile morphoosteological features (O'Gorman et al. 2014a) but some show relatively large sized elements compared to other juvenile elasmosaurids (Otero et al. 2012, O'Gorman et al. 2013). One explanation for this pattern is that the aristonectines retain juvenile features until they reach larger sizes relative to other elasmosaurids (O'Gorman 2013, O'Gorman et al. 2014a). To test this, Araújo et al. (2015) described the palaeohistology of a juvenile aristonectine from Angola and recorded features which are more compatible with an adult specimen. The present contribution includes a description of MLP 14-I-20-8 (specimen from the Museo de La Plata, Buenos Aires Province, Argentina), the most complete and smallest aristonectine juvenile postcranial specimen from Antarctica, the first palaeohistological description of an Antarctic aristonectine and some insights into the probable morphological changes that occurred during the ontogeny of the Aristonectinae.

\section{Geological setting}

The López de Bertodano Formation crops out both in Seymour Island (Isla Marambio) and Vega Island (Sandwich Bluff Member), James Ross Archipelago, Antarctic Peninsula (Fig. 1c). The Maastrichtian López de Bertodano Formation comprises approximately $1150 \mathrm{~m}$ of sandy shales and sandstones with interbedded concretions and carbonate subordinate facies (Macellari 


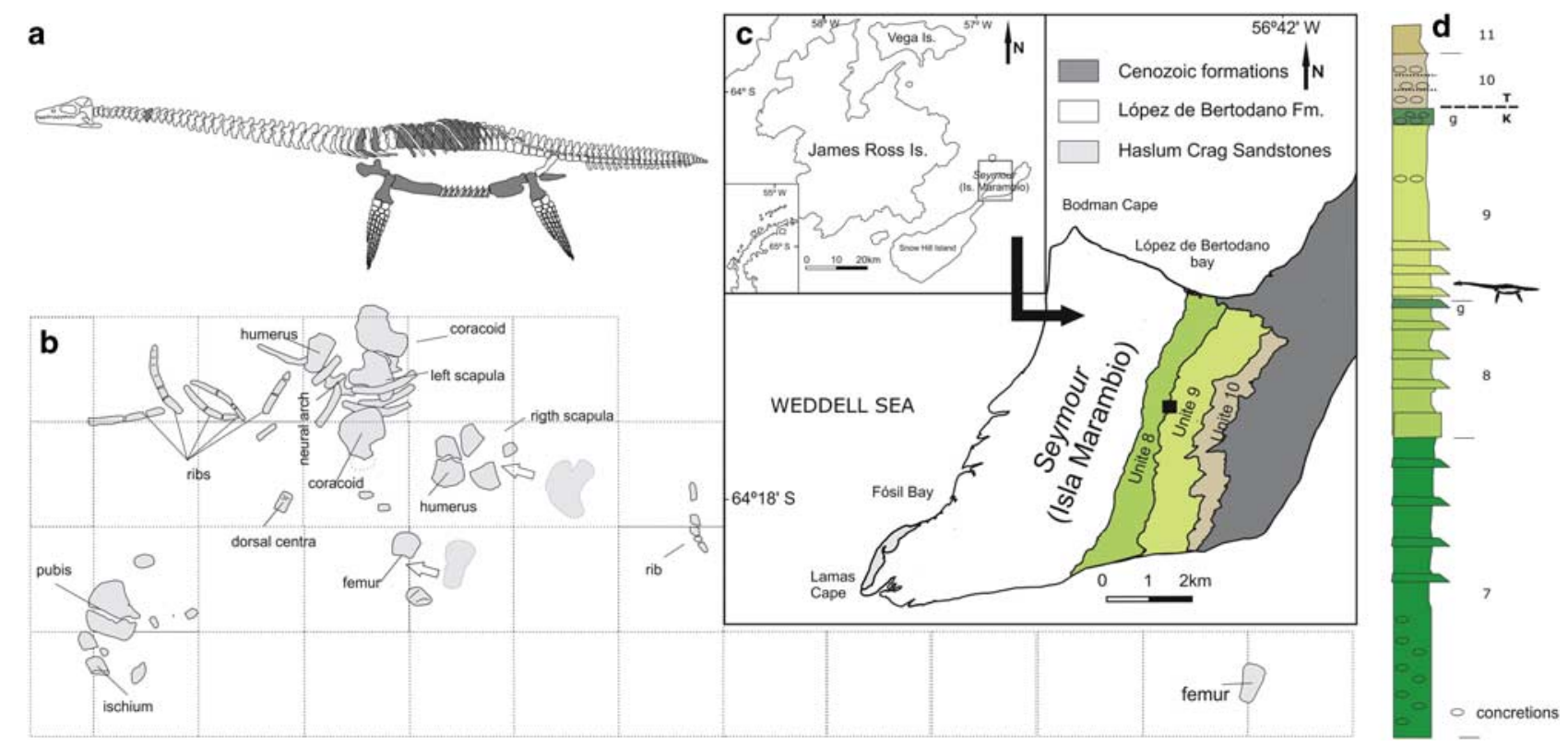

Fig. 1. Aristonectinae indet. MLP 14-I-20-8 preserved material, locality and horizon. a. Materials preserved. b. Quarry diagram, squares $=200 \times 200 \mathrm{~mm}$. c. Map showing the locality of MLP 14-I-20-8 discovery. d. Upper section of the López de Bertodano Formation indicating the level where the MLP 14-I-20-8 was positioned, modified from Montes et al. (2013).

1988). The outcrops of the López de Bertodano Formation at Seymour Island were originally divided into ten units (Klb 1-10), but recently unit $\mathrm{Klb} 1$ has been considered to be part of the Haslum Crag Sandstone (Macellari 1988, Olivero et al. 2008).

The lower units, Klb 2-6 (the informal 'rotularia units'), were deposited in a shallow marine environment near an estuary (Macellari 1988, Olivero et al. 2008). While the upper units, Klb 7-10 ('molluscan units'), where the specimen described in this contribution was collected (between Klb 8 and 9), were deposited in a middle to outer platform environment (Macellari 1988). The López de Bertodano is Maastrichtian-Danian in age (Olivero et al. 2000). Specifically, it is interesting that the Maastrichtian-Danian boundary is approximately between Klb 9 and 10 (top of the 'molluscan units') (Macellari 1988).

\section{Methods}

\section{Description and comparison of external morphology}

The ontogenetic categories proposed by Brown (1981), which are based on the fusion of the neural arch to the vertebral centrum, are considered. For descriptive purposes, Welles' (1952) indices have been used. These indices considered vertebral centrum proportions, specifically the height $(\mathrm{H}) /$ length $(\mathrm{L})$ ratio $(\mathrm{HI}=100 \times \mathrm{H} / \mathrm{L})$ and breadth (B)/length $(\mathrm{L})$ ratio $(\mathrm{BI}=100 \times \mathrm{B} / \mathrm{L})$. Additionally, the breadth/height ratio $(\mathrm{BHI}=100 \times \mathrm{B} / \mathrm{H})$ and the vertebral length index $(\mathrm{VLI}=100 \times \mathrm{L} /(0.5 \times(\mathrm{H}+\mathrm{B})))$ (Brown 1981) were also recorded. The $\mathrm{B}$ and $\mathrm{H}$ were measured on the posterior articular face. Finally, the B:L index (Welles 1952), which records the ratio between the distal breadth and total length of propodials, was calculated. The body length of MLP 14-I-20-8 was estimated through comparison with SGO PV 260 (Otero et al. 2012, fig. 2; specimen from the Área Paleontología, Museo Nacional de Historia Natural, Santiago, Chile), a juvenile aristonectine from the Quiriquina Formation, Chile, identified as Aristonectes quiriquinensis (Otero et al. 2014). The comparison is based on the assumption that both MLP 14-I-20-8 and SGO PV 260 have similar body proportions.

\section{Palaeohistological analysis}

Palaeohistological samples were taken from the middiaphyseal of the right humerus of MLP 14-I-20-8. Three thin sections were prepared using standard palaeohistological techniques and examined with light microscopy (Chinsamy \& Raath 1992). Nomenclature and definitions of structures used in this study are derived from Francillon-Vieillot et al. (1990) and Chinsamy-Turan (2005).

\section{Systematic palaeontology}

Sauropterygia Owen 1860

Plesiosauria de Blainville 1835 
a

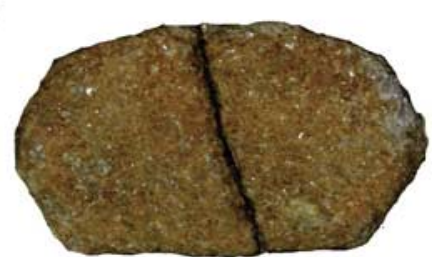

e

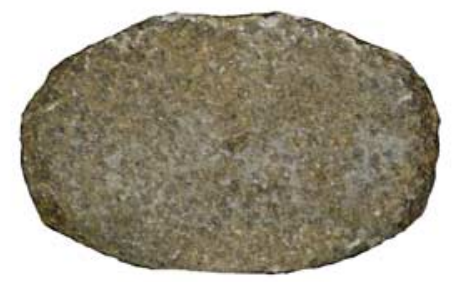

i

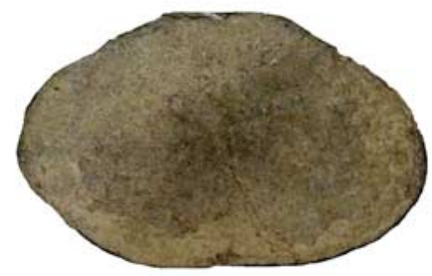

m

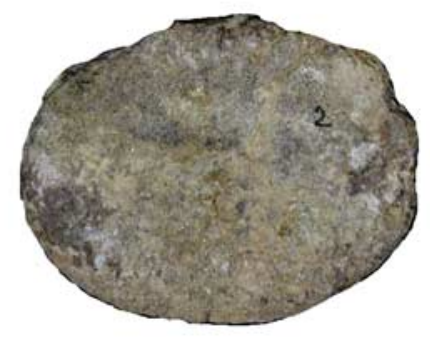

b

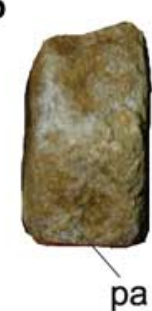

f

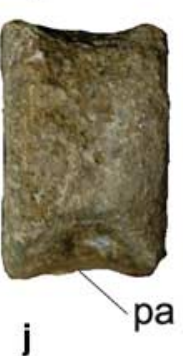

j

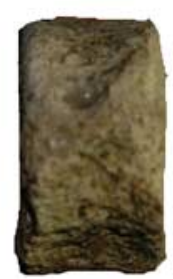

n

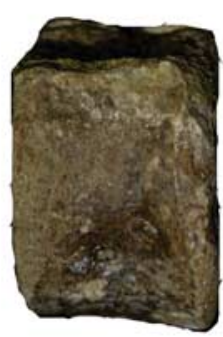

C

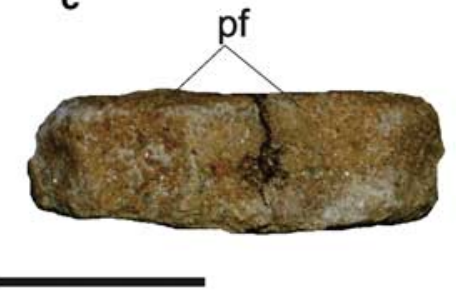

g

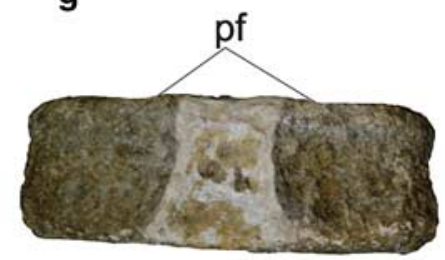

k

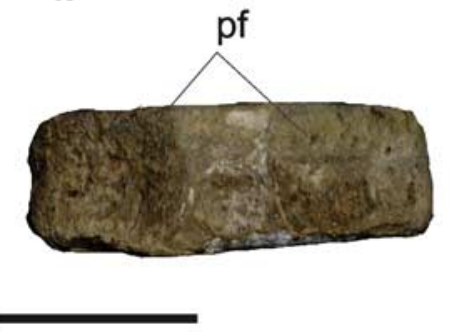

o

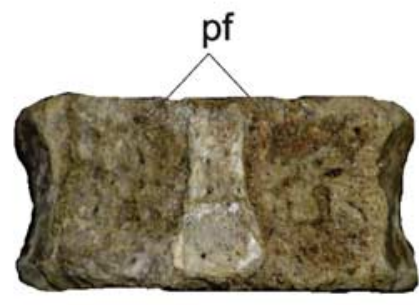

d

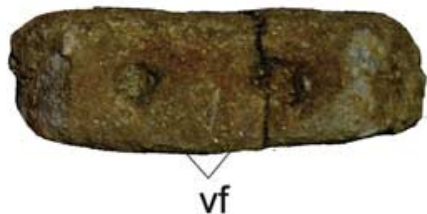

h

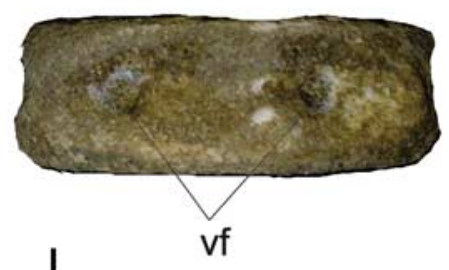

I

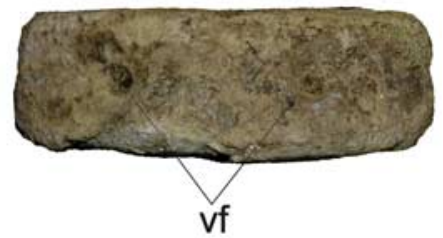

p

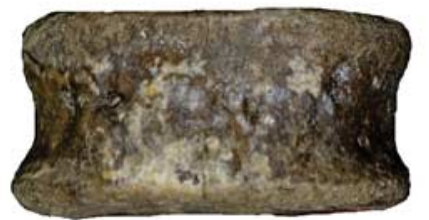

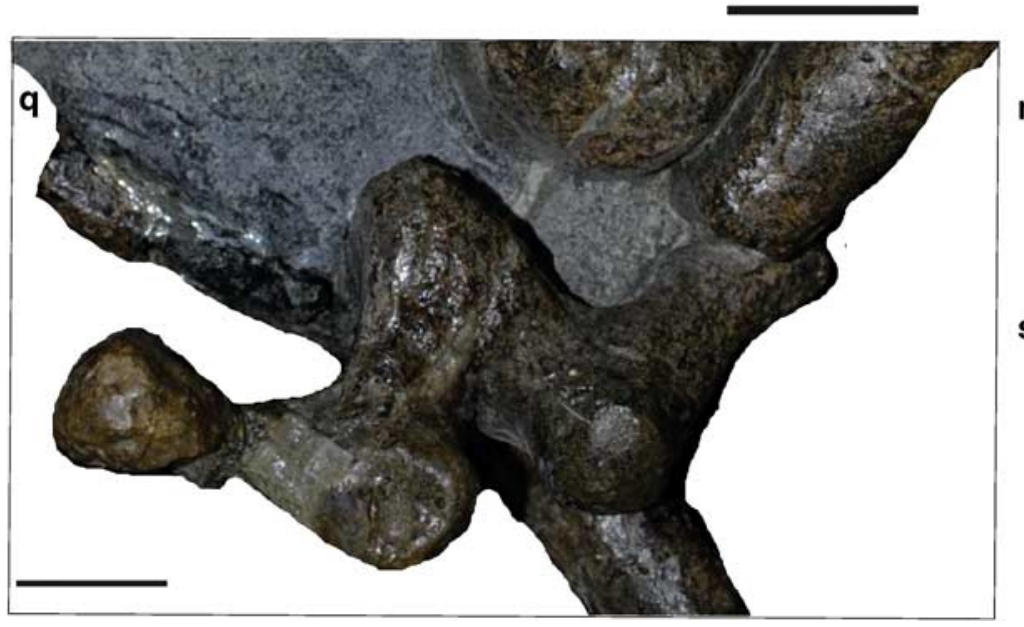

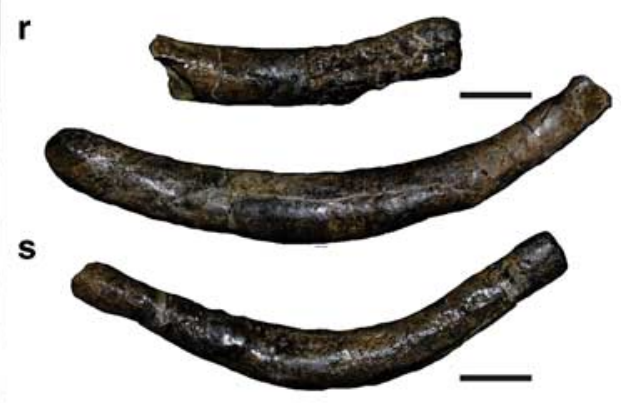

Fig. 2. Aristonectinae indet. MLP 14-I-20-8. Anterior cervical centrum in a. anterior, b. left lateral, c. dorsal and d. ventral views. Posterior cervical centrum in e. anterior, f. left lateral, g. dorsal and $\mathbf{h}$. ventral views. Pectoral centrum in $\mathbf{i}$. anterior, j. left lateral, k. dorsal and $\mathbf{l}$. ventral views. Dorsal centrum in $\mathbf{m}$. anterior, n. left lateral, o. dorsal and p. ventral views. q. Dorsal neural arch detail. r. Dorsal ribs. s. Gastralia. Scale bar $=20 \mathrm{~mm}$. pa $=$ parapophyses, $\mathrm{pf}=$ pedicellar facet, $\mathrm{vf}=$ ventral foramina. 


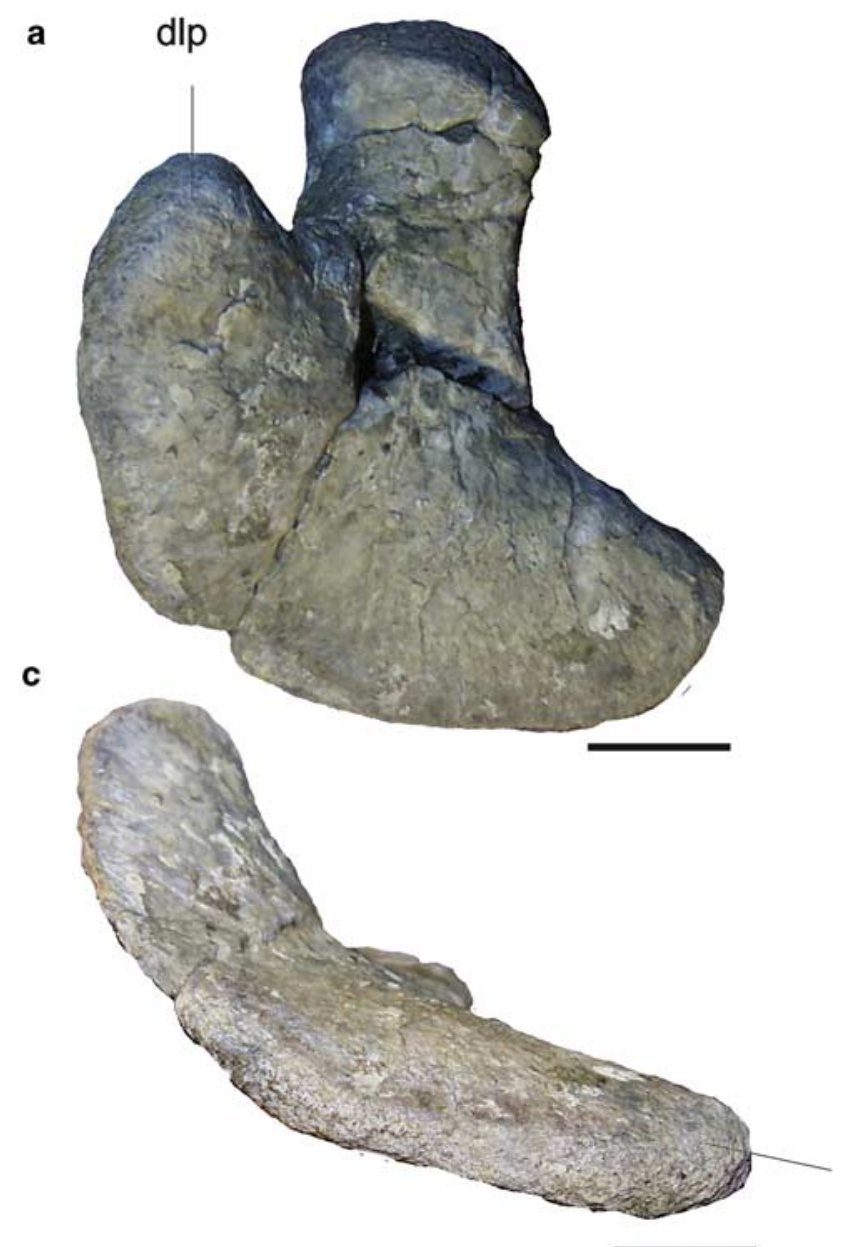

e

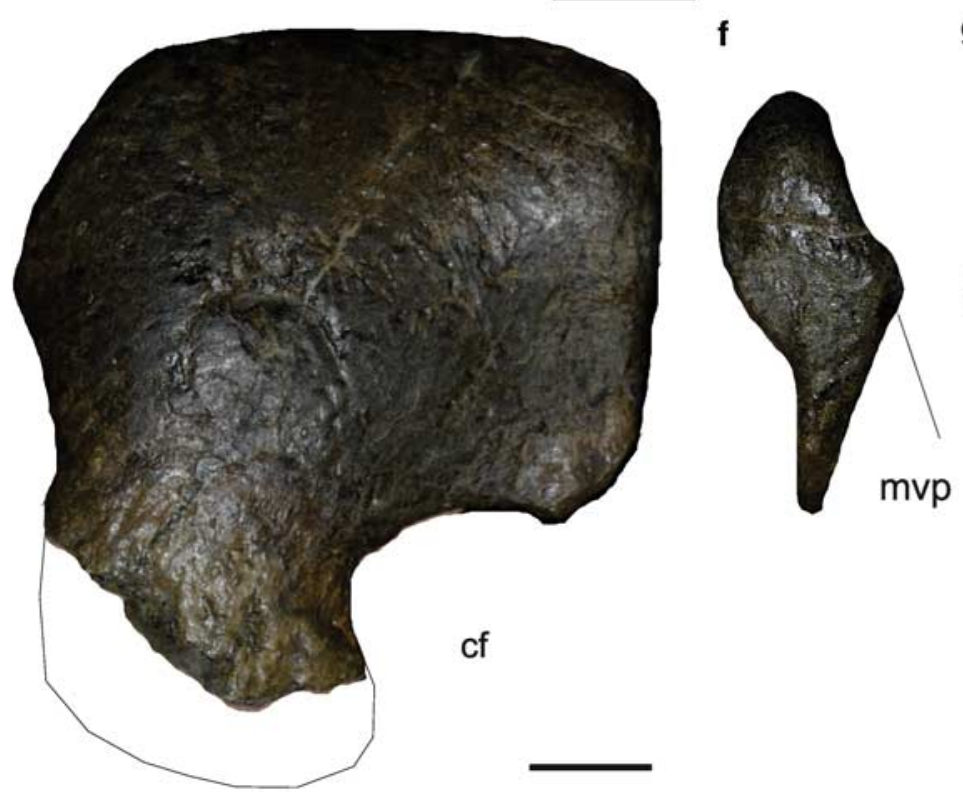

b

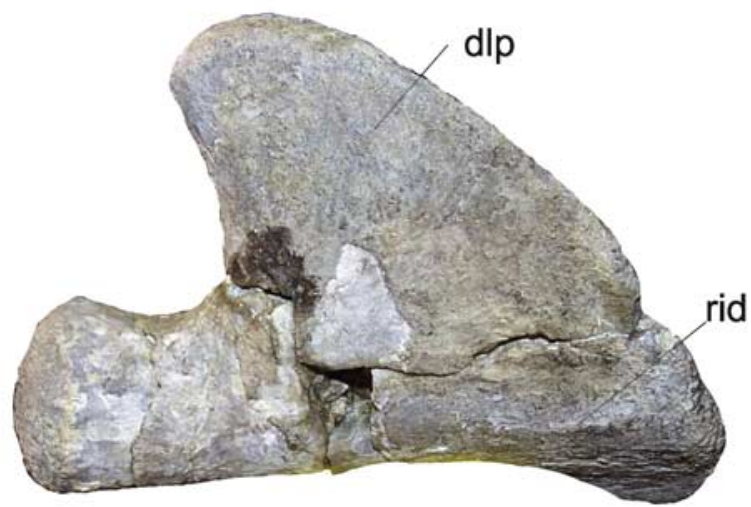

d dlp

g

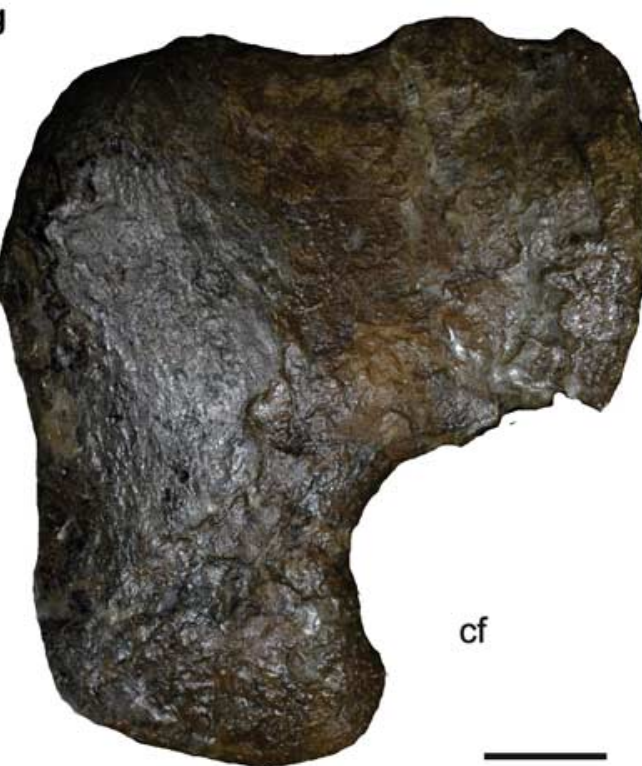

Fig. 3. Aristonectinae indet. MLP 14-I-20-8. Right scapula in a. dorsal, b. right lateral, c. anterior and d. medial views. Left coracoid in e. dorsal and f. symphyseal views. g. Left coracoid in ventral view. Scale bar $=20 \mathrm{~mm}$. dlp $=$ dorsolateral process, $\mathrm{mvp}=$ midventral process, rid $=$ ridge, $\mathrm{vr}=$ ventral ramus. 
a

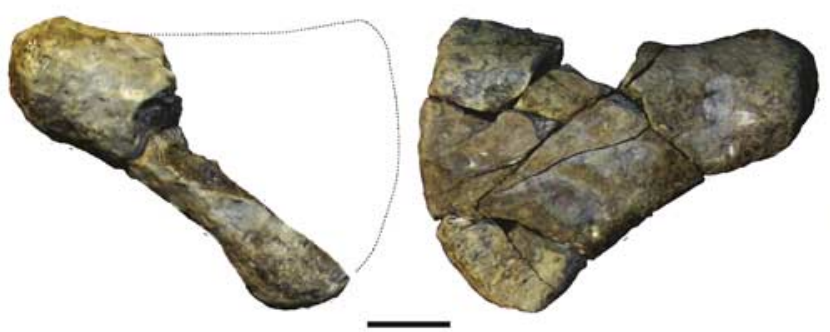

d

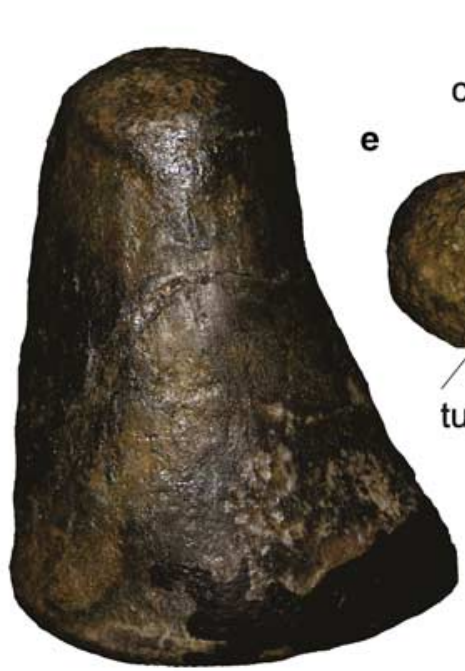

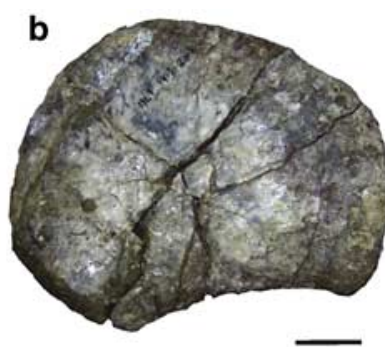

g
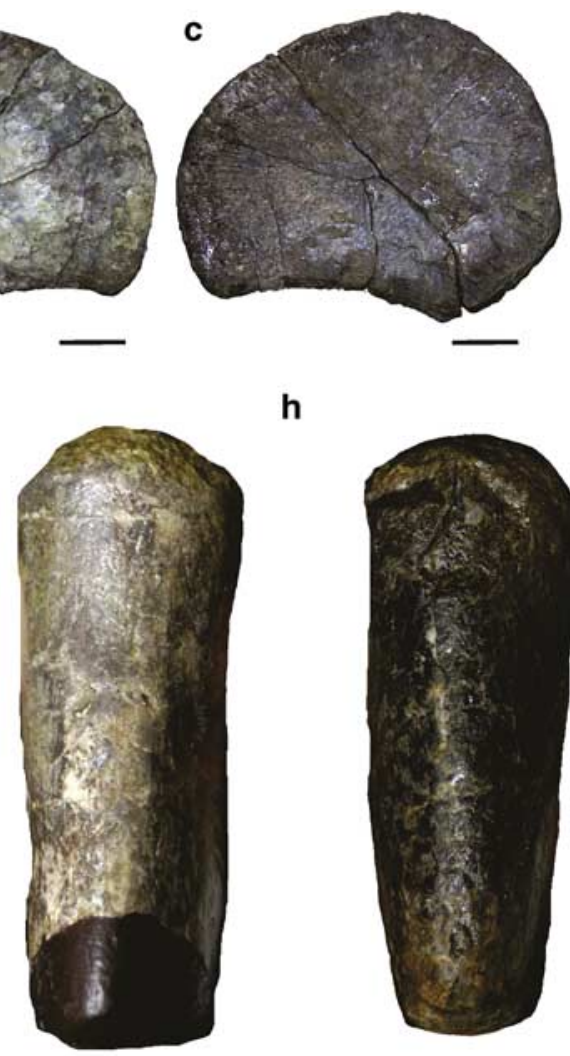

h

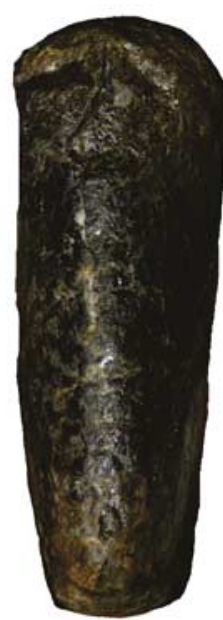

I

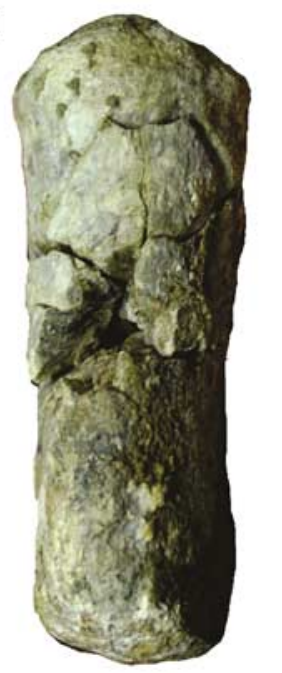

m

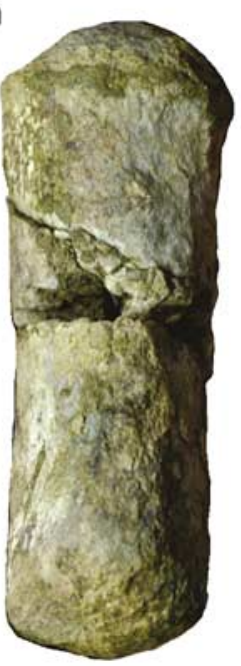

Fig. 4. Aristonectinae indet. MLP 14-I-20-8. a. Ischia in dorsal? views. Pubis in b. dorsal and $\mathbf{c}$. ventral views. Left humerus in d. dorsal, e. proximal, f. ventral, g. posterior and h. anterior. Left femur in i. ventral, j. proximal, k. dorsal, l. posterior and m. anterior. Scale bar $=20 \mathrm{~mm}$. cap $=$ capitulum, tro $=$ trochanter, tub $=$ tuberosity.

Plesiosauroidea Welles 1943

Elasmosauridae Cope 1869

Aristonectinae O'Keefe \& Street 2009

(sensu Otero et al. 2012)

Aristonectinae

Figs 2-4

\section{Material}

MLP 14-I-20-8 is a postcranial skeleton comprising two cervical, one pectoral and seven dorsal vertebrae, both coracoids, scapulae, pubes, ischia, humeri, femora dorsal ribs and gastralia. The palaeohistological samples 

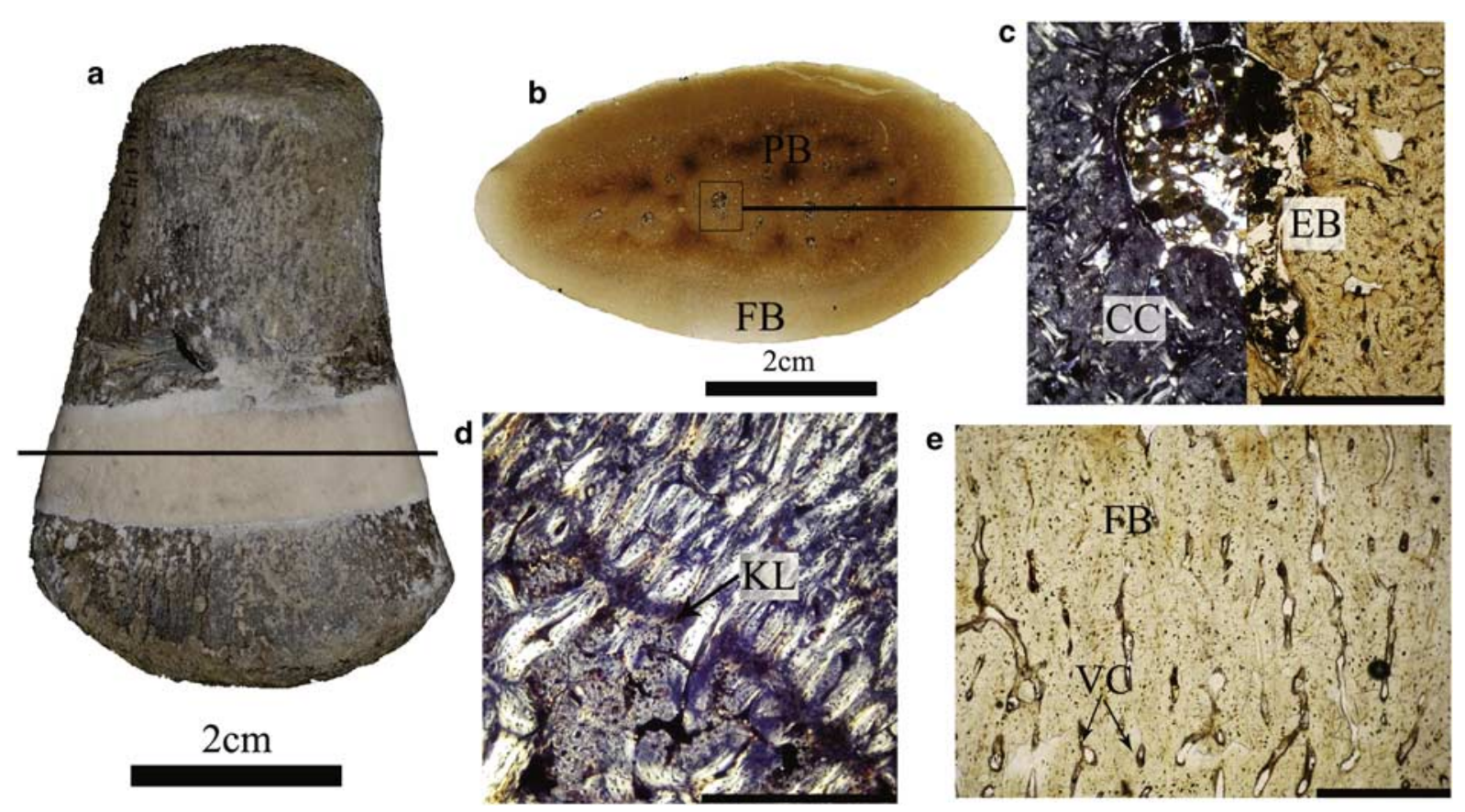

Fig. 5. Histology and microstructure of MLP 14-I-20-8. a. Right humerus, black line indicates the approximate position of the thin section. Scale bar $=2 \mathrm{~cm}$. b. General view of the thin section. Scale bar $=2 \mathrm{~cm}$. c. General view of the medullar region showing abundant calcified cartilage with some erosion cavities, and deposition of endosteal bone. Scale bar $=0.5 \mathrm{~cm}$. d. The medullar and cortical tissues are separated by a Kastschenko's line. Scale bar $=1.75 \mathrm{~cm}$. e. General view of the cortical bone showing abundant vascular canals. Scale bar $=0.75 \mathrm{~cm}$. Normal light. $\mathrm{CC}=$ calcified cartilage, $\mathrm{EB}=$ endosteal bone, $\mathrm{FB}=$ fibrolamellar bone, $\mathrm{KL}=$ Kastschenko's line, $\mathrm{PB}=$ primary bone, $\mathrm{VC}=$ vascular canals.

were taken from the middle shaft of the right humerus (Fig. 5a).

\section{Locality and horizon}

Seymour Island $\left(64^{\circ} 16^{\prime} 53.7^{\prime \prime} \mathrm{S}, 56^{\circ} 45^{\prime} 21.00^{\prime \prime} \mathrm{W}\right)$ James Ross Archipelago, Antarctic Peninsula. López de Bertodano Formation, limit between $\mathrm{Klb} 8$ and 9, Upper Maastrichtian (Fig. 1d) (Macellari 1988).

Table I. Aristonectinae indet. (MLP 14-I-20-8) measurements of vertebral centra (length (L), height $(\mathrm{H})$, breadth $(\mathrm{B}) \mathrm{in} \mathrm{mm}$ ) and height index $(\mathrm{HI}, 100 \times \mathrm{H} / \mathrm{L})$, breadth index $(\mathrm{BI}, 100 \times \mathrm{B} / \mathrm{L})$, breadth-height index $(\mathrm{BHI}, 100 \times \mathrm{B} / \mathrm{H})$ and vertebral length index $(\mathrm{VLI}, \mathrm{L} /(0.5 \times$ $(\mathrm{H}+\mathrm{B}))) . \mathrm{c}=$ cervical, $\mathrm{p}=$ pectoral and $\mathrm{d}=$ dorsal.

\begin{tabular}{llllllll}
\hline & L & H & B & HI & BI & BHI & VLI \\
\hline c1 & 13.6 & 22.9 & 39.2 & 168 & 288 & 171 & 44 \\
c2 & 16.2 & 27.6 & 44.2 & 170 & 273 & 160 & 45 \\
p1 & 16 & 27 & 44 & 169 & 275 & 163 & 45 \\
d1 & 21 & 33 & 43 & 157 & 205 & 130 & 55 \\
d2 & 20 & 32 & 42.5 & 160 & 213 & 133 & 54 \\
d3 & 19 & 31 & 44 & 163 & 232 & 142 & 51 \\
d4 & 20 & 28 & 39 & 140 & 195 & 139 & 60 \\
d5 & 21 & 30 & 41 & 143 & 195 & 137 & 59 \\
d6 & 22 & 27.2 & 42.1 & 124 & 191 & 155 & 63 \\
d7 & 20 & 29.2 & - & 146 & - & - & - \\
\hline
\end{tabular}

\section{Results}

\section{Morphological description}

The MLP 14-I-20-8 was collected within an area of $1.2 \mathrm{~m}^{2}$. Only the left femur was displaced, probably by recent weathering.

\section{Axial skeleton}

Only two cervical centra are preserved and, as in the other vertebrae, they do not have the neural arches associated with the centra. Both centra are broader than high and higher than long (Table I). The pedicellar facets are rectangular shaped (Fig. 2c \& g). The floor of the neural channel of the larger centra bears two foramina (Fig. 2g). The articular facets are elliptical but the smaller and anterior centra show almost flat dorsal and ventral limits (Fig. 2a). Both preserved cervical centra show a ventrolateral parapophysis (Fig. 2a \& f). The ventral surface is flat in the smaller centrum and slightly transversely convex in the larger cervical centrum. Both centra show two ventral foramina separated by a rounded transversely broad 'ventral keel' (Fig. 2d \& h) that is $29 \%$ anterior and $41 \%$ posterior of the centra transverse width.

One putative pectoral vertebra is preserved. It differs from the cervical centra by the inclined pedicellar facets 
and the absence of independent parapophysis (Fig. 2i \& j). In general proportions, it is similar to the posterior-most cervical preserved. The ventral surface is pierced by two widely spaced foramina (Fig. 21).

Seven dorsal centra are preserved, none of which have the neural arch and centra articulated. All dorsal centra are broader than high and higher than long (Table I). The pedicellar facets are mostly square in outline and only slightly laterally inclined (Fig. $2 \mathrm{~m}$ ). The articular faces are almost flat and elliptical in shape but with their dorsal areas divided into three parts: the two laterals correspond to the pedicellar facets and the medial third to the base of the neural canal (Fig. 2m). The lateral sides of the centra are slightly concave anteroposteriorly (Fig. 2n \& o). Ventrally, two to four circular foramina are observed (Fig. 2p).

The dorsal neural arches are stocky elements with rounded pedicels and almost cylindrical diapophysis (Fig. 2q). The neural spines are short with a posterior rounded keel.

The dorsal ribs have a circular or elliptical cross-section, with a slightly concave proximal end (Fig. 2r), whereas the gastralia are shorter and strongly bent with a pointy ended apex (Fig. 2s).

\section{Appendicular skeleton}

Both scapulae and coracoids are preserved. The glenoid ramus of the scapula is stocky and it shows a slightly thicker acetabular facet and a smaller, triangular shaped coracoid facet proximally (Fig. 3a-d). However, the limit between both facets is not clear, indicating an extremely immature morphological stage. The typical domes and valleys of the surface observed in adult aristonectines (O'Gorman 2013, fig. 6.1.8.D) are absent. The ventral ramus is large and slightly ventromedially directed. The dorsolateral process is anteroposteriorly wide $(55 \mathrm{~mm})$ and proximodistally short $(32 \mathrm{~mm})$. The dorsal tip of the dorsolateral ramus is located far anteriorly to the distal end of the glenoid ramus ( $18 \mathrm{~mm}$ of $94 \mathrm{~mm}$ total length). The anterior margin of the ventral ramus and dorsolateral process is strongly convex (Fig. $3 \mathrm{a} \& \mathrm{~d}$ ). Ventrally, there is a faint ridge between the ventral ramus and the dorsolateral process (Fig. 3b).

The coracoid has the typical shape observed in elasmosaurids. The glenoid ramus bears well-defined scapular and glenoid facets (Fig. 3g). The anterior margin, between the glenoid ramus and the anterior process, is slightly concave (Fig. 3g). The symphyseal surface (Fig. 3f) exhibits a mid-ventral process located in the medial margin of the ventral surface (Fig. 3f). There is a rounded posterior ramus distally expanded that in the distal end shows the typical expansion (Fig. 3g). The posterior ramus limits the cordiform fenestra
Table II. Aristonectinae indet. (MLP 14-I-20-8) appendicular skeleton measurements.

\begin{tabular}{|c|c|}
\hline & $\begin{array}{l}\text { Measurement } \\
\quad(\mathrm{mm})\end{array}$ \\
\hline \multicolumn{2}{|l|}{ Scapula } \\
\hline Scapula length & 94 \\
\hline Glenoid ramus mediolateral width & 34 \\
\hline $\begin{array}{l}\text { Dorsolateral process anteroposterior length } \\
\text { (proximal) }\end{array}$ & 55 \\
\hline $\begin{array}{l}\text { Dorsolateral process anteroposterior length } \\
\text { (distal) }\end{array}$ & 27 \\
\hline Dorsolateral process length & 36 \\
\hline Mediolateral width & 98 \\
\hline Glenoid ramus length & 25 \\
\hline \multicolumn{2}{|l|}{ Right coracoid } \\
\hline Anteroposterior length & 120 \\
\hline Anterior transverse width & 104 \\
\hline Posterior transverse width & 56.5 \\
\hline Minimum transverse width & 53 \\
\hline Maximum symphyseal width & 23.8 \\
\hline \multicolumn{2}{|l|}{ Left coracoid } \\
\hline Symphyseal length & 76 \\
\hline \multicolumn{2}{|l|}{ Right/left humerus } \\
\hline Length & $91 / 85$ \\
\hline Distal breadth & $? / 66$ \\
\hline \multicolumn{2}{|l|}{ Right/left femur } \\
\hline Length & $79 / 88$ \\
\hline Distal breadth & $48 / 54$ \\
\hline \multicolumn{2}{|l|}{ Right ischia } \\
\hline Mediolateral width & 94.7 \\
\hline Anteroposterior symphyseal length & 69.9 \\
\hline Anteroposterior acetabular length & 29.8 \\
\hline \multicolumn{2}{|l|}{ Pubis } \\
\hline Anteroposterior length & 96.5 \\
\hline Mediolateral width & 114.9 \\
\hline Thickness of acetabular area & 21.8 \\
\hline
\end{tabular}

(Fig. 3e \& g). The medial anterior and posterior processes are only slightly developed (Fig. 3e \& g).

Both pubes are preserved. They are rounded, stocky and broader than long (Fig. $4 \mathrm{~b} \& \mathrm{c}$ ). The anterior margin is strongly convex without an anterolateral projection (Fig. 4b \& c). A developed pelvic bar is absent. Only the right ischium is complete. The ischia have the typical 'inverted L-shape' and although the posterior ramus is not elongated it is larger than the anterior ramus (Fig. 4a). The thickest zone corresponds to the acetabulum. The symphyseal margin shows a thicker zone near the anterior margin.

Both humeri and femora are preserved. The humeri are rounded, stocky and dorsoventrally compressed (Fig. $4 \mathrm{~d}-\mathrm{h}$, Table II). The proximal end forms the capitulum, but the trochanter is not well differentiated (Fig. 4e). The distal end is anteroposteriorly expanded (Fig. $4 \mathrm{~d} \& \mathrm{f}$ ). The femora are stocky and dorsoventrally compressed, proportionally similar to the humerus but slightly shorter and more gracile (Fig. 41-m, Table II). The proximal end forms the capitulum, but as in the humerus, a trochanter is not differentiated (Fig. 4j). The distal end of the femur is 
Table III. Aristonectinae indet. (MLP 14-I-20-8) body length estimation based on comparison of elements of MLP 14-I-10-8 and SGO PV 260 (5.5-6 m in length). Ratio M/S = ratio of length of element in MLP 14-I-10-8 over SGO PV 260.

\begin{tabular}{lcccc}
\hline & Length $(\mathrm{mm})$ & & Ratio M/S & Body length estimation (m) \\
& MLP 14-I-20-8 & SGO PV 260 & Minimum, maximum \\
\hline Posterior cervical vertebrae & 16.2 & 45 & 0.36 & $1.98,2.16$ \\
Coracoid & 120 & 468 & 0.26 & $1.41,1.53$ \\
Ischium & 69.9 & 250 & 0.28 & $1.54,1.68$ \\
\hline
\end{tabular}

anteroposteriorly expanded, the posterior expansion being larger than the anterior one (Fig. $4 \mathrm{i} \& \mathrm{k}$ ).

\section{Histology and microstructure}

The whole section has a compact inner organization and no open medullary cavity (Fig. 5b). The medullary region is filled with a calcified cartilaginous core, showing remodelling processes with some erosion cavities and deposition of endosteal bone (Fig. 5c). These tissues are separated from the rest of the cortex by a distinct change in organization and a Kastschenko's line (Fig. 5d). The cortex is entirely formed by fibrolamellar bone tissue consisting of a woven fibred matrix, isotropic under crossed polarized light (Fig. 5e). The cortical woven fibred bone is highly vascularized by simple radial and longitudinal vascular canals. The inner cortex shows osteocyte lacunae, irregularly shaped and randomly oriented with a few canalicular channels close to the medullary region that become more abundant near the outer cortex (Fig. 5e). The outer cortex, separated from the inner cortex by a distinct change in bone tissue, probably due to diagenetic alteration, contains a few osteocyte lacunae with a few canalicular channels. Bone tissues of all sections are characterized by the lack of primary or secondary osteons. Growth marks (annuli or lines of arrested growth) are also absent in the cortical bone.

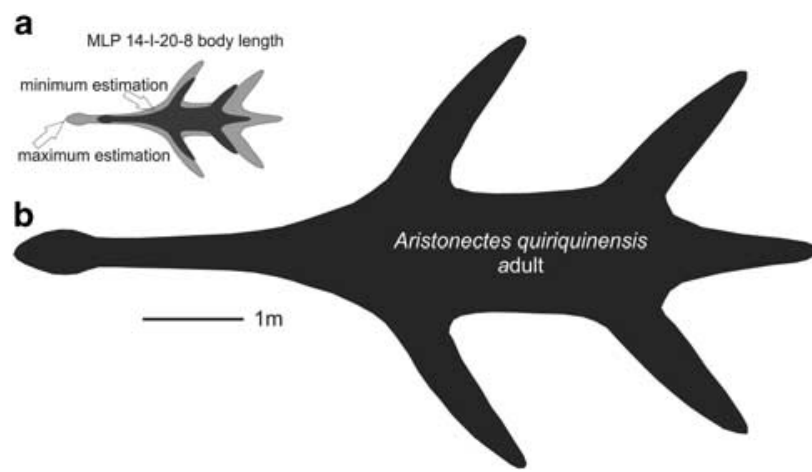

Fig. 6. Body length diagrams. a. Maximum and minimum estimated body length of MLP 14-I-20-8. a. Adult body length of Aristonectes quiriquinensis (SGO PV 957) taken from Otero et al. (2014).

\section{Calculation}

Body length

As many elements as possible were considered for the body length comparison between MLP 14-I-20-8 and SGO PV 260, including posterior cervical vertebrae, coracoid and ischia (Tables I, II \& III). The SGO PV 260 body length is estimated to be between $5.5-6 \mathrm{~m}$ (Otero, personal communication 2015). Table III presents a ratio for the axial length for each element: M/S = MLP specimen measurement/SGO specimen measurement. A maximum and minimum estimation for MLP 14-I-20-8 body length was calculated by $(\mathrm{M} / \mathrm{S}) \times 6 \mathrm{~m}$ and $(\mathrm{M} / \mathrm{S}) \times$ $5.5 \mathrm{~m}$, respectively. In summary, by comparing the measurements of the three elements, a maximum and minimum estimation of body length $(2.16$ and $1.41 \mathrm{~m}$, respectively) is obtained.

The estimated body length of the adult of $A$. quiriquinensis is $8 \mathrm{~m}$ (Otero et al. 2014), and therefore, the juvenile is $3.7-5.7 \mathrm{~m}$, smaller than the adult form of the SGO PV 260 (A. quiriquinensis) (see Fig. 6)

\section{Discussion}

\section{Maturity}

According to the size-independent criteria used in plesiosaurs for osteological maturity determination (Brown 1981, Otero et al. 2012, O’Gorman et al. 2014a), MLP 14-I-20-8 corresponds to a juvenile. Neural arches are not fused with centra, the sutures between the ribs and vertebral centra are not closed, bone edges are mainly rounded and the articular faces of the appendicular bones are poorly defined. Bone microstructure and histological data are consistent with those of the macromorphology and also indicate that MLP 14-I-20-8 was a perinatal individual at death. As this specimen was not found associated with a female, and distinction between unborn and new born is very difficult to assess, we use the term 'perinatal' in the sense of Horner et al. (2001). The evidence supporting a perinatal stage of the MLP 14-I-20-8 includes the incomplete endochondral ossification (i.e. retention of a calcified cartilaginous core in the medullary region), the predominance of primary bone tissue without secondary 


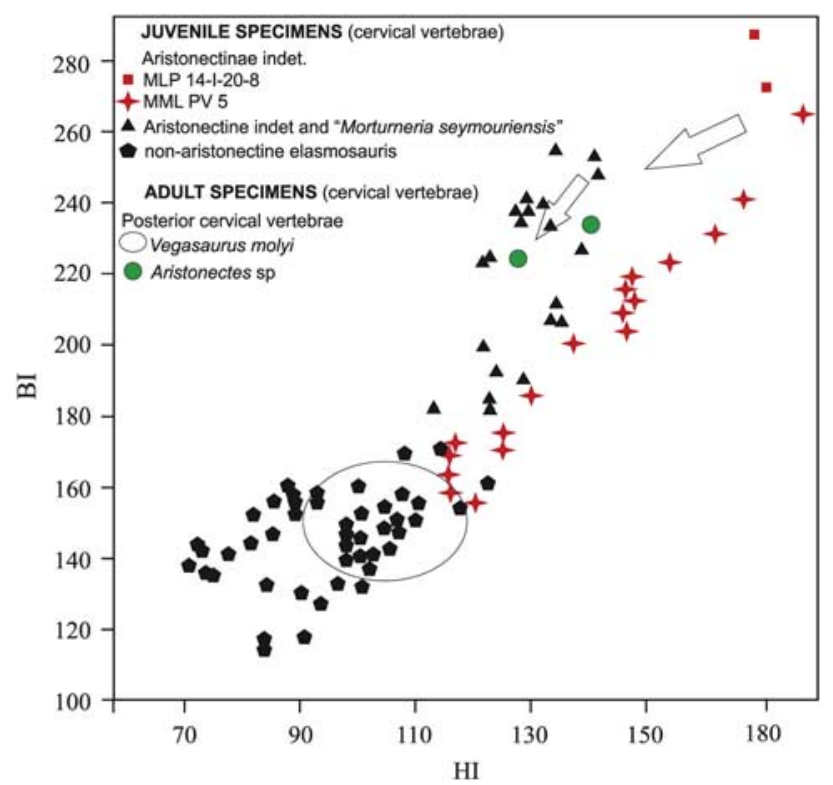

Fig. 7. Bivariate diagram (HI-BI) of cervical centrum values of juvenile aristonectine and non-aristonectine elasmosaurids and posterior cervical centrum values of adult Aristonectes sp. and the non-elasmosaurid Vegasaurus molyi (data taken from Welles 1943, O'Gorman 2013, O'Gorman et al. 2013, 2014a, 2014b, 2015). Black triangles: Aristonectinae indet. specimens CM Zfr 104, MLP 89-III-3-2, MML PV 192, MUC PV 131 and Morturneria seymourensis specimen TTUP 9219, black pentagons: non-aristonectine elasmosaurid specimens AMNH 5261, CIT 2832, MLP 93XII-20-1, MLP 99-XII-1-8, AM F9630-9928, MLP-86-X-28(2-6), oval: non-aristonectine elasmosaurid specimen MLP 93-I-5-1 Vegasaurus molyi, green circles: Aristonectes sp. specimen MLP 89-III-3-1. Arrows indicate ontogenetic change in vertebral centrum proportions.

Institution abbreviations: AM = Australian Museum, Sydney, Australia, AMNH = American Museum Natural History, New York, USA, CIT = California Institute of Technology, Pasadena, CA, USA, MLP = Museo de La Plata, Buenos Aires Province, Argentina, MML = Museo Municipal de Lamarque, Río Negro Province, Argentina, MUC $=$ Museo de la Universidad del Comahue, Neuquén Province, Argentina, NZGS = Institute of Geological and Nuclear Sciences, Lower Hutt, New Zealand,

TTUP = Museum of Texas Tech University, Lubbock, TX, USA.

remodelling, the lack of primary or secondary osteons and growth marks in the cortical bone, and the open vascular spaces not surrounded by a thin coat of lamellar bone tissue (this last feature suggests the lack of an early formation of primary osteons). Another significant characteristic is the presence of the Kastschenko's line (Francillon-Vieillot et al. 1990, Ricqlés et al. 2001). In growing long bones this peculiar structure is a thin remaining coat of cartilage matrix that persists in the periphery of the young diaphysis after the condroblasts destroy most of the hypertrophic cartilage to produce the marrow cavity (Francillon-Vieillot et al. 1990).

When endosteal and periosteal bones are deposited centripetally and centrifugally, respectively, Kastschenko's line separates them providing a clear evidence that the first periosteal bone deposit has not yet been reabsorbed by perimedullar osteoclasts (Francillon-Vieillot et al. 1990). The bone tissues of MLP 14-I-20-8 are exclusively formed by highly vascularized woven fibred bone, in which the channels within the bone are large and unfilled with deposits of lamellar bone (simple vascular canals) of a woven matrix. This bone pattern is characteristic of embryos and of very fast growing young individuals, especially among higher vertebrates (Francillon-Vieillot et al. 1990), and it is considered as an unambiguous indication of a high absolute rate $\left(\mu \mathrm{m} \mathrm{day}^{-1}\right)$ of periosteal accretion (De Buffrénil \& Mazin 1990, Horner et al. 2001, Klein et al. 2015)

\section{Systematic affinities}

Although the MLP 14-I-20-8 specimen is incompletely preserved some conclusions about its systematic affinities can be made. MLP 14-I-20-8 has clear elasmosaurid affinities due to the presence of a coracoid with a posterior cordiform fenestra (Carpenter 1999, Ketchum \& Benson 2011).

Systematic determination of juvenile elasmosaurids is a complex issue because of the great ontogenetic variation of the osteological features (Brown 1981, Carpenter 1999). Nonetheless, some information about the affinities of MLP 14-I-20-8 can be obtained using bivariate graphs based on cervical central proportions (O'Gorman et al. 2013, 2014a, Otero \& O'Gorman 2013). The bivariate diagram in Fig. 7 shows a plot of the cervical vertebrae indexes for MLP 14-I-20-8. The proportions of MLP 14-I-20-8 are more similar to those recorded in aristonectines than in juvenile nonaristonectines elasmosaurids. Pending the discovery of additional diagnostic material, we refer MLP 14-I-20-8 to an indeterminate genus and species of Aristonectinae.

\section{Change of proportion in elements among aristonectine}

Aristonectines show, as do other elasmosaurids, a marked modification of the morphology through the ontogeny (Carpenter 1999), generating, as was previously mentioned, difficulties in systematic determination of juvenile specimens. However, there have been no attempts to describe this variation systematically.

The ontogenetic changes of the proportions of the cervical vertebrae have been recorded among elasmosaurids, mostly related to vertebral elongation (O'Keefe \& Hiller 2006). Figure 7 shows the $\mathrm{HI}$ and $\mathrm{BI}$ values of the cervical vertebrae and the proportion of change in the posterior-most cervical 


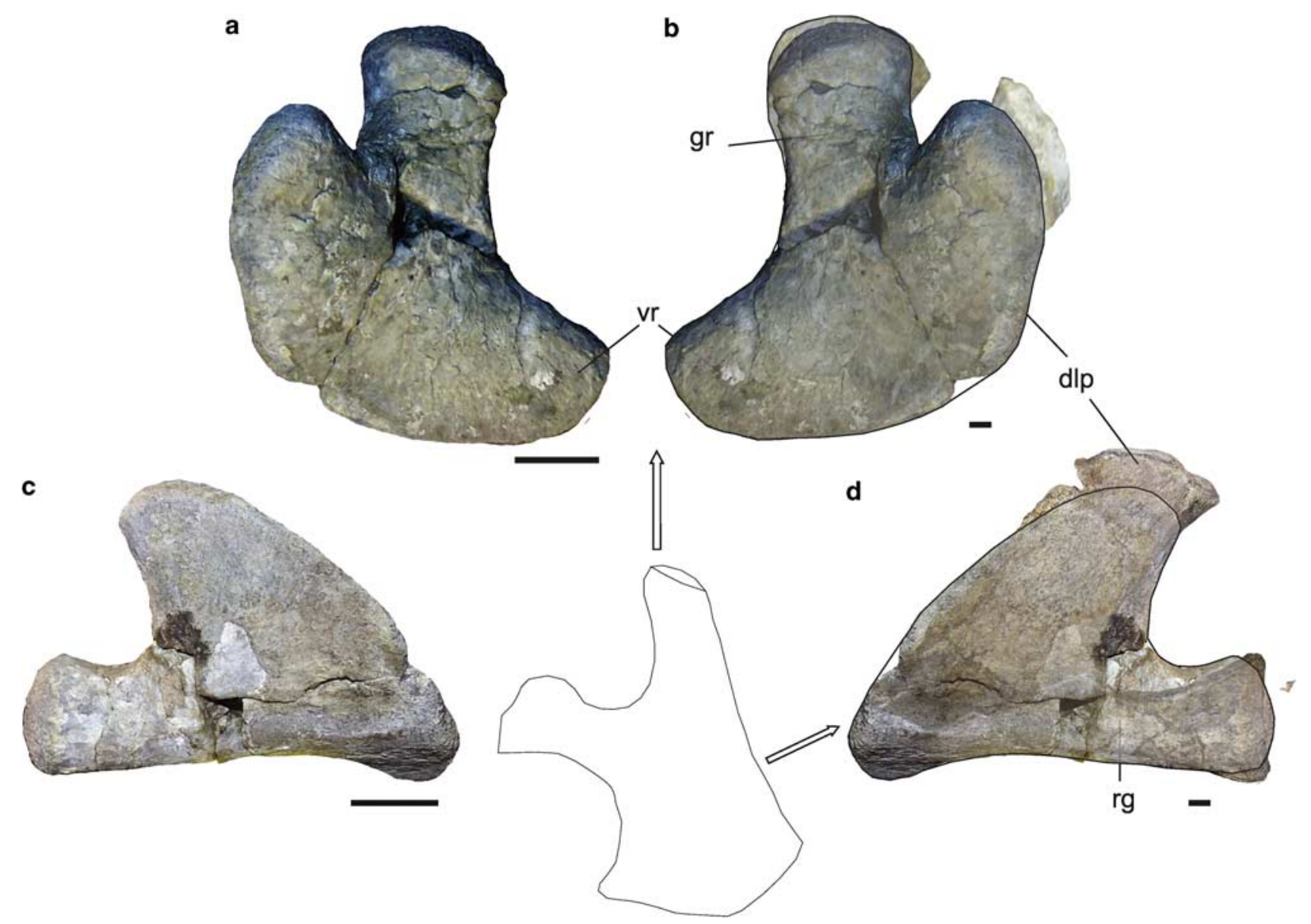

Fig. 8. Comparison between juvenile Aristonectinae indet. (MLP 14-I-20-8) and adult Aristonectes sp. (MLP 89-III-3-1). Right scapula in a. dorsal and c. lateral views. MLP 14-I-20-8 (reversed) and MLP 89-III-3-1 superposed in b. dorsal and d. lateral views. Scale bar $=20 \mathrm{~mm}$. $\mathrm{dlp}=$ dorsolateral process, $\mathrm{gr}=$ glanoid ramus, $\mathrm{vr}=$ ventral ramus. Scapula diagram modified from Hiller et al. 2005.

vertebrae. This modification involves strong decreases of the $\mathrm{HI}$ and less marked decreases of the BI, indicating that the increases in $\mathrm{L}$ are related to $\mathrm{H}$ and $\mathrm{B}$. However, this trend

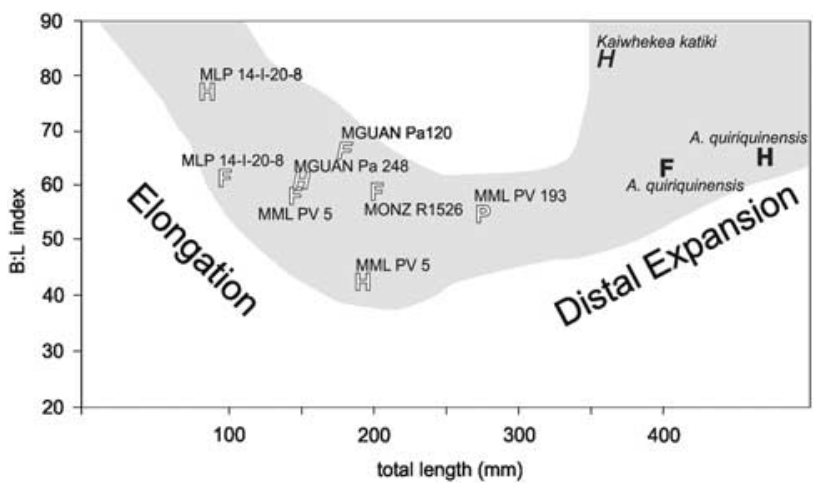

Fig. 9. Bivariate diagram B:L and length of several aristonectine propodials. Hollow letters indicate juveniles. Black letters indicate adult specimens (data taken from O’Gorman 2013, Otero et al. 2014, Araújo et al. 2015). Italics indicate approximate values. does not continue, as the posterior cervical vertebrae of adult aristonectines show higher BI values relative to those recorded for non-aristonectine elasmosaurids (Fig. 7, O’Gorman 2013).

The scapula of MLP 14-I-20-8 was compared with the scapulae of the MLP 89-III-3-1 specimen identified as Aristonectes sp. (O'Gorman et al. 2014b). Figure 8 shows that the glenoid ramus is relatively stockier and shorter, differing in the convexity of the dorsolateral ramus from convex sides (juvenile) and parallel sides (adult) in the dorsolateral process. Additionally, it clearly shows the anteroposterior length of the dorsolateral process to be greater in the juvenile than in the adult. The ventrolateral ramus cannot be compared because it is not complete in MLP 89-III-3-1.

Figure 9 shows the B:L index and the total length of Aristonectinae propodials. The pattern seems to indicate that the ontogenetic change goes through two stages: the first is characterized by decreases in $\mathrm{B}: \mathrm{L}$, and the second shows an increase of length and B:L, indicating progressive development of the distal expansion. 


\section{Baseline model of Aristonectinae ontogeny}

The Aristonectinae shows some features that have intrigued palaeontologists since the XIX century, even before the description of Aristonectes. The descriptions of A. parvidens (Cabrera 1941), Kaiwhekea katiki (Cruickshank \& Fordyce 2002) and A. quiriquinensis (Otero et al. 2014) provide information about the general morphology of aristonectines. The consequent recognition of the elasmosaurian affinities of aristonectines (Gasparini et al. 2003, Ketchum \& Benson 2011, Otero et al. 2012, O'Gorman et al. 2013) allows us to compare the derived aristonectine morphology with the non-aristonectine morphology of the classic elasmosaurids. Several reasons, such as cervical morphology characterized by relatively short and wide centra (Cruickshank \& Fordyce 2002, Gasparini et al. 2003) and a relatively large body size of osteologically immature (juvenile) specimens indicate possible participation of pedomorphic processes during the evolution of the aristonectine morphology (O'Gorman 2013, O'Gorman et al. 2014a). Additionally, palaeohistological evidence recorded by Araújo et al. (2015) indicates adult or sub-adult features in osteologically immature specimens. The MLP 14-I-20-8 specimen described here represents an earlier stage before remodelling, consistent with the 'perinatal' stage, and therefore, younger than that recorded by Araújo et al. (2015), enabling future comparative work with juvenile non-aristonectine elasmosaurids.

Finally, the specimen and the perinatal condition are consistent with the hypothesis that the Antarctic Peninsula was a breeding area for marine reptiles (Martin et al. 2007) during the last part of the Cretaceous.

\section{Acknowledgements}

The authors thank the IAA (Instituto Antártico Argentino) and Fuerza Aérea Argentina for support in the field, Juan José Moly for help with the extraction of the specimen, Marcelo Reguero for allowing the study of the material, and P. Arregui for improvement of the English in this article. The authors would also like to thank E. Fordyce. This research was supported by PIP 0433, UNLP N 607, and PICT 2012-0748, PICT 2013-0663 and PIUNRN 40-A-404. The authors are also grateful to the reviewers for their comments on the manuscript.

\section{Author contribution}

José Patricio O'Gorman analysed the morphological data and wrote the paper. Marianella Talevi analysed the palaeohistological data and wrote the paper. Marta Fernández wrote the paper.

\section{References}

Araújo, R., Polcyn, M.J., Lindgren, J., Jacobs, L.L., Schulp, A.S., Mateus, O., Gonçalves, A.O. \& Morais, M.L. 2015. New aristonectine elasmosaurid plesiosaur specimens from the Early Maastrichtian of Angola and comments on paedomorphism in plesiosaurs. Netherlands Journal of Geosciences - Geologie en Mijnbouw, 94, 93-108.

Brown, D.S. 1981. The English Upper Jurassic Plesiosauroidea (Reptilia) and a review of the phylogeny and classification of the Plesiosauria. Bulletin of the British Museum (Natural History) Geology, 35, 253-347.

Buffrénil, V.D. \& MAZIN, J.M. 1990. Bone histology of the ichthyosaurs: comparative data and functional interpretation. Paleobiology, 16, 435-447.

Cabrera, A. 1941. Un Plesiosaurio nuevo de Cretáceo del Chubut. Revista del Museo de la Plata (Nueva Serie). 2, 113-130.

CArpenter, K. 1999. Revision of North American elasmosaurs from the Cretaceous of the western interior. Paludicola, 2, 148-173.

Chinsamy, A. \& RaAth, M.A. 1992. Preparation of fossil bone for histological examination. Palaeontologia Africana, 29, 39-44.

Chinsamy-Turan, A. 2005. The microstructure of dinosaur bones: deciphering biology through fine scale techniques. Baltimore, MD: Johns Hopkins University Press, 216 pp.

Cope, E.D. 1869. Extinct Batrachia, Reptilia and Aves of North America. Transactions of the American Philosophical Society, 14, 1-252.

Cruickshank, A.R.I. \& Fordyce, R.E. 2002. A new marine reptile (Sauropterygia) from New Zealand: further evidence for a Late Cretaceous austral radiation of cryptoclidid plesiosaurs. Palaeontology, 45, 557-575.

De Blainville, H.D. 1835. Description de quelques espèces de reptiles de la Californie, précédée de l'analyse d'un système général d'Erpétologie et d'Amphibiologie. Nouvelles Annales du Muséum (National) d'Histoire Naturelle, Paris, 4, 233-296.

Francillon-Vieillot, H., de Buffrénil, V., Castanet, J., Géraudie, J., Meunier, F.J., Sire, J.Y., Zylberberg, L. \& de RicQlés, A. 1990. Microstructure and mineralization of vertebrate skeletal tissues. In Carter, J.G., ed. Skeletal biomineralization: patterns, processes and evolutionary trends. New York, NY: Van Nostrand Reinhold, 471-530.

Gasparini, Z., Bardet, N., Martin, J.E. \& Fernández, M. 2003. The elasmosaurid Aristonectes Cabrera from the latest Cretaceous of South America and Antarctica. Journal of Vertebrate Paleontology, 23, $104-115$.

Hiller, N., Mannering, A.A., Jones, C.M. \& Cruickshank, A.R. 2005. The nature of Mauisaurus haasti Hector, 1874 (Reptilia: Plesiosauria). Journal of Vertebrate Paleontology, 25, 588-601.

Horner, J.R., Padian, K. \& DE Ricqlès, A. 2001. Comparative osteohistology of some embryonic and perinatal archosaurs: developmental and behavioral implications for dinosaurs. Paleobiology, 27, 39-58.

Ketchum, H.F. \& Benson, R.B. 2011. A new pliosaurid (Sauropterygia, Plesiosauria) from the Oxford Clay Formation (Middle Jurassic, Callovian) of England: evidence for a gracile, longirostrine grade of Early-Middle Jurassic pliosaurids. Studies on Fossil Tetrapods, No. 86, 109-129.

Klein, N., Houssaye, A., Neenan, J.M. \& Scheyer, T.M. 2015. Long bone histology and microanatomy of Placodontia (Diapsida: Sauropterygia). Contributions to Zoology, 84, 59-84.

Kubo, T., Mitchell, M.T. \& Henderson, D.M. 2012. Albertonectes vanderveldei, a new elasmosaur (Reptilia, Sauropterygia) from the Upper Cretaceous of Alberta. Journal of Vertebrate Paleontology, 32, 557-572.

Macellari, C.E. 1988. Stratigraphy, sedimentology, and paleoecology of Upper Cretaceous/Paleocene shelf-deltaic sediments of Seymour Island. Geological Society of America Memoirs, 169, 25-54. 
Martin, J.E., Sawyer, J.F., Reguero, M. \& Case, J.A. 2007. Occurrence of a young elasmosaurid plesiosaur skeleton from the Late Cretaceous (Maastrichtian) of Antarctica. USGS OF-2007-1047, Short Research Paper 066, 10.3133/of2007-1047.srp066.

Montes, M., Nozal, F., Santillana, S., Marenssi, S. \& Olivero, E. 2013. Mapa Geológico de la isla Marambio (Seymour) Escala 1: 20.000. Serie Cartográfica Geocientífica Antártica.

O'Gorman, J.P. 2012. The oldest elasmosaurs (Sauropterygia, Plesiosauria) from Antarctica, Santa Marta Formation (upper Coniacian? Santonian-upper Campanian) and Snow Hill Island Formation (upper Campanian-lower Maastrichtian), James Ross Island. Polar Research, 31, 10.3402/polar.v31i0.11090.

O'Gorman, J.P. 2013. Plesiosaurios del Cretácico Superior de Patagonia y Península Antártica. PhD thesis, Facultad de Ciencias Naturales y Museo, Universidad Nacional de La Plata, 527 pp. [Unpublished]. Available at: http://sedici.unlp.edu.ar/bitstream/handle/10915/26140/ Tomo_I Documento completo.pdf?sequence $=4$.

O'Gorman, J.P., Gasparini, Z. \& Salgado, L. 2013. Postcranial morphology of Aristonectes (Plesiosauria, Elasmosauridae) from the Upper Cretaceous of Patagonia and Antarctica. Antarctic Science, 25, 71-82.

O'Gorman, J.P., Gasparini, Z. \& Salgado, L. 2014a. Reappraisal of Tuarangisaurus? cabazai (Elasmosauridae, Plesiosauria) from the upper Maastrichtian of northern Patagonia, Argentina. Cretaceous Research, 47, 39-47.

O'Gorman, J.P., Salgado, L., Olivero, E.B. \& Marenssi, S.A. 2015. Vegasaurus molyi, gen. et sp. nov. (Plesiosauria, Elasmosauridae), from the Cape Lamb Member (lower Maastrichtian) of the Snow Hill Island Formation, Vega Island, Antarctica, and remarks on Weddellian Elasmosauridae. Journal of Vertebrate Paleontology, 35, $10.1080 / 02724634.2014 .931285$.

O'Gorman, J.P., Olivero, E.B., Santillana, S., Everhart, M.J. \& Reguero, M. 2014b. Gastroliths associated with an Aristonectes specimen (Plesiosauria, Elasmosauridae), López de Bertodano Formation (upper Maastrichtian) Seymour Island (Is. Marambio), Antarctic Peninsula. Cretaceous Research, 50, 228-237.

O'KeEFe, F.R. \& Hiller, N. 2006. Morphologic and ontogenetic patterns in elasmosaur neck length, with comments on the taxonomic utility of neck length variables. Paludicola, 5, 206-229.

O'KeEFe, F.R. \& StreEt, H.P. 2009. Osteology of the cryptocleidoid plesiosaur Tatenectes laramiensis, with comments on the taxonomic status of the Cimoliasauridae. Journal of Vertebrate Paleontology, 29, 48-57.

Olivero, E.B. \& Medina, F.A. 2000. Patterns of Late Cretaceous ammonite biogeography in southern high latitudes: the family Kossmaticeratidae in Antarctica. Cretaceous Research, 21, 269-279.
Olivero, E.B., Ponce, J.J. \& Martinioni, D.R. 2008. Sedimentology and architecture of sharp-based tidal sandstones in the upper Marambio Group, Maastrichtian of Antarctica. Sedimentary Geology, 210, 11-26.

Otero, R.A. \& O'Gorman, J.P. 2013. Identification of the first postcranial skeleton of Aristonectes Cabrera (Plesiosauroidea, Elasmosauridae) from the upper Maastrichtian of the south-eastern Pacific, based on a bivariate graphic analysis. Cretaceous Research, 41, 86-89.

Otero, R.A., Soto-Acuña, S. \& Rubilar-Rogers, D. 2012. A postcranial skeleton of an elasmosaurid plesiosaur from the Maastrichtian of central Chile, with comments on the affinities of Late Cretaceous plesiosauroids from the Weddellian Biogeographic Province. Cretaceous Research, 37, 89-99.

Otero, R.A., Soto-Acuña, S., O'Keefe, F.R., O'Gorman, J.P., Stinnesbeck, W.S., Suárez, M.E., Rubilar-Rogers, D., Salazar, C. \& Quinzio-SinN, L.A. 2014. Aristonectes quiriquinensis, sp. nov., a new highly derived elasmosaurid from the upper Maastrichtian of central Chile. Journal of Vertebrate Paleontology, 34, 100-125.

OwEN, R. 1860. On the orders of fossil and recent Reptilia, and their distribution in time. Reports of the British Association for the Advancement of Science, 29, 153-166.

Ricqlés, A., Se, M.O., Antunes, M. \& Taquet, P. 2001. Histomorphogenesis of embryos of Upper Jurassic theropods from Lourinhã (Portugal). Comptes Rendus de l'Académie des Sciences IIA Earth and Planetary Science, 332, 647-656.

Vincent, P., Bardet, N., Suberbiola, X.P., Bouya, B., Amaghzaz, M. \& Meslouh, S. 2011. Zarafasaura oceanis, a new elasmosaurid (Reptilia: Sauropterygia) from the Maastrichtian Phosphates of Morocco and the palaeobiogeography of latest Cretaceous plesiosaurs. Gondwana Research, 19, 1062-1073.

WelLes, S.P. 1943. Elasmosaurid plesiosaurs with description of new material from California and Colorado. Memoirs of the University of California, 13, 125-254.

Welles, S.P. 1952. A review of the North American Cretaceous elasmosaurs. University of California Publications in Geological Sciences, 29, 47-144.

WeLles, S.P. 1962. A new species of elasmosaur from the Aptian of Columbia and a review of the Cretaceous plesiosaurs. University of California, Publications in the Geological Sciences, 44, 1-96.

ZINSMEISTER, W.J. 1979. Biogeographic significance of the late Mesozoic and early Tertiary molluscan faunas of Seymour Island (Antarctic Peninsula) to the final break-up of Gondwanaland. In GrAY, J. \& Boucot, A.J., eds. Historical biogeography, plate tectonics and the changing environment. Corvallis, OR: Oregon State University Press, 349-355. 